\title{
Editorials
}

\section{A mayor for London}

In May last year Londoners elected a mayor by direct vote for the first time. The mayor and the London Assembly, together forming the Greater London Authority (GLA), have an electorate of seven million people and command resources of almost 6 billion euros. Four appointed committees - the police authority, the fire and emergency planning authority, Traffic for London and the London Development Agency-oversee major services for the capital. But the Greater London Authority also has a "duty to promote the health of Londoners and to take into account the effect of its policies on health."

The United Kingdom has decentralisation of power more in theory than in practice. While cities, and their rural counterparts, counties, have been responsible for local taxes and services since the 19th century, in recent years central government has increased pressure to achieve national "standards" for education, housing and welfare services across the country. The National Health Service, created in 1948 and funded from central taxes, has decentralised management authorities (regularly changing in structure), but these are appointed by central government and never controlled by locally elected politicians.

New parliaments for Scotland and Wales, elected in 1999, have changed the balance of power. To match these, the government developed eight regional offices in England-still directly controlled by Westminster-for several of the main ministries, including health. However, this year, as a pre-election gesture of "cutting bureaucracy", the minister of health has decided to close the regional health offices and reduce the number of local health authorities from 100 to 30 (and probably five in London). Health authorities are not elected, nor will they match any other devolved government body: observers of the long game predict their demise at the hands of a future minister.

The department of health's public health strategy for England, Saving lives: our healthier nation ${ }^{2}$ focuses on reducing accidents, cancer, coronary heart disease and mental illness through prevention and improved health care. At the same time, 26 deprived areas, including three in London, have been selected as Health Action Zones and given extra funds for joint work with local authorities on the determinants of health. ${ }^{3}$ Given these existing public health objectives at national and local level, what extra can a London mayor do?

Transport is a political issue because the mayor (and public sentiment) opposes the government's neoconservative policy of privatisating London Underground. ${ }^{4}$ (London's surface railways and buses were privatised by the previous Conservative government, and there are no plans to buy them back into public ownership.) From a public health perspective, transport policy should promote walking and cycling and reduce car journeys, which would increase cardiovascular health through exercise and reduce road accidents. ${ }^{5}$ This is in line with the recommendation of London's planning advisory committee to reduce London traffic by an average of $15 \%$ over the next decade through a mixture of road use and parking charges, reallocation of road space and improved public transport. ${ }^{6}$ Evidence from the Netherlands suggests that controlling growth of air traffic from London's several international airports would also contribute to health.

Environmental pollution in London has a range of health impacts. ${ }^{89}$ Air pollution is of great public concern, and with recognised effects on respiratory health. ${ }^{10}$ The pollution is mainly from motor vehicles, particularly goods vehicles and taxis, and could be overcome by both cleaner technology (such as electric vehicles) and traffic reduction. Waste disposal in London has fallen far behind best practice in other European countries. ${ }^{11}$ Household waste is still floated by barge to landfill sites in the Thames estuary, and construction waste is taken by lorries to private tips. To comply with European Community directives, far more waste will need to be incinerated, using technology that minimises air pollution. The incinerators can also provide power for local heating, leading to another environmental objective of energy conservation and contributing low cost heating for elderly people at risk of hypothermia. London has 372 service reservoirs and 96 water treatment plants. End user monitoring has shown falling levels of chemical pollution, ${ }^{12}$ but an outbreak of Cryptosporidiosis (with 345 confirmed cases) in 1997 has triggered new investment for monitoring drinking water at source.

Economic planning is perhaps the most contentious area. The government's current economic policies for London emphasise local regeneration through employment, using both national and European funds. People working in inner west London (including the City of London) have an average income per head six times that in outer east London. ${ }^{13}$ Almost $40 \%$ of the London's wealth is now produced by the financial and business sector; and $20 \%$ of London's workforce live outside London itself, and take their income to the surrounding "home" counties. With the added momentum of continuous migration both into and out from London, retaining London's wealth for people living within London will be a major challenge for the mayor.

The 33 London local authorities (with their boundaries unchanged since 1966) will continue to have important public responsibilities that contribute to health, including public education, housing, social services and environmental health services. In 1995 the 16 London NHS district public health departments created a small statistical surveillance unit, the Health of Londoners Project, which has produced a public health report for London ${ }^{14}$ as well as reports on specific policy areas and comparisons between European capital cities. ${ }^{15}$ The unit has now been absorbed into a London Health Observatory, funded by central government and part of a national network of health observatories. $^{16}$

There has been some jostling for public health influence at the mayor's table. The central government's regional office for health, accountable to the government rather than to Londoners, put forward proposals for a London health strategy, ${ }^{17}$ and established a presence within the new Greater London Authority. A promising result has been to provide early "health impact assessment" commentaries on policies that the mayor is developing in nine strategic areas (which include transport, environment, regeneration and energy). It is yet to be tested whether this advice will be translated into health promoting policies. The Kings Fund, 
a well endowed charity established a century ago through funds contributed by Londoners, has promoted a "London Health Commission" which brings together "stakeholders" from different organisations. The commission is large, self appointed, and without a budget or executive power.

Across Europe, public health works through a range of structures at both regional and local level. ${ }^{18}{ }^{19}$ The London mayor does not control the National Health Service in London, but has the potential to make decisions that promote health. Will the Greater London Authority assess, debate and act on the health impacts of its own policies? In the city of Chadwick, Snow and Morris, ${ }^{20}$ how will public health be practised in the 21 st century?

MARK MCCARTHY

Department of Epidemiology and Public Health,

University College London,

1-19 Torrington Place,

London WC1E 6BT, UK

1 http://www.london.gov.uk/gla/health.htm (accessed 8 May 2001)

2 Department of Health. Saving lives: our healthier nation. London: The Stationery Office, 1999.

3 http://www.haznet.org.uk/ (accessed 8 May 2001)

4 Pollock A. Funding London Underground: financial myths and economic realities. London: Listen to London, 2000.
5 Soderlund N, Ferguson J, McCarthy M. Transport in London and the implications for health. London: Health of Londoners Project, 1996. London Planning Advisory Committee. Supplementary advice on a strategy for road traffic reduction in London. London: London Planning Advisory

7 Health Council of the Netherlands. Committee on the health impact of large airports. The Hague: Health Council of the Netherlands, 1999. (199/14E)

8 McCarthy M. Environment, pollution and health. Report to the NHE Executive London Regional Office, 1999 (http://www.ucl.ac.uk/public-health/ london.html, accessed 8 May 2001).

9 McCarthy M, Ferguson J. Environment and health in London. London: Kings Fund, 1999 (http://www.ucl.ac.uk/public-health/london.html, accessed 8 May 2001).

10 Committee on the Medical Effects of Air Pollutants. Quantification of the effects of air pollution on health in the United Kingdom. London: Department of Health, 1998.

11 London Waste Regulatory Authority. Today's waste, tomorrow's resources: the waste management plan for greater London, 1995-2015. London: London Waste Regulatory Authority, 1995. Drining

2 Drinking. Water Inspectorate. Annual report 1998. (http// www.dwi.detr.gov.uk/pubs/annrep98/24.htm, accessed 22 March 2000).

13 Matheson J, Holding A, eds. Focus on London. London: The Stationery Office, 1999 .

14 Bardsley M, Barker M, Bhan A, et al, eds. The health of Londoners: a public health report for London. London: Kings Fund, 1998.

15 Project Mégapoles: health in Europe's capitals. Luxembourg: European Commission, 1999 (CE-V/3-99-015-EN-C).

$16 \mathrm{http}: / /$ www.pho.org.uk, accessed 8 May 2001.

17 London's health: developing a vision together. London: NHS Executive London Regional Office, 2000.

18 McCarthy M, Rees S. Health systems and public health medicine in the European Community. London: Royal College of Physicians, 1992.

19 Green G. Health and governance in European cities. Copenhagen: World Health Organisation, 1998.

20 Morris JN. Tomorrow's community physician. Lancet 1969;ii:811-16.

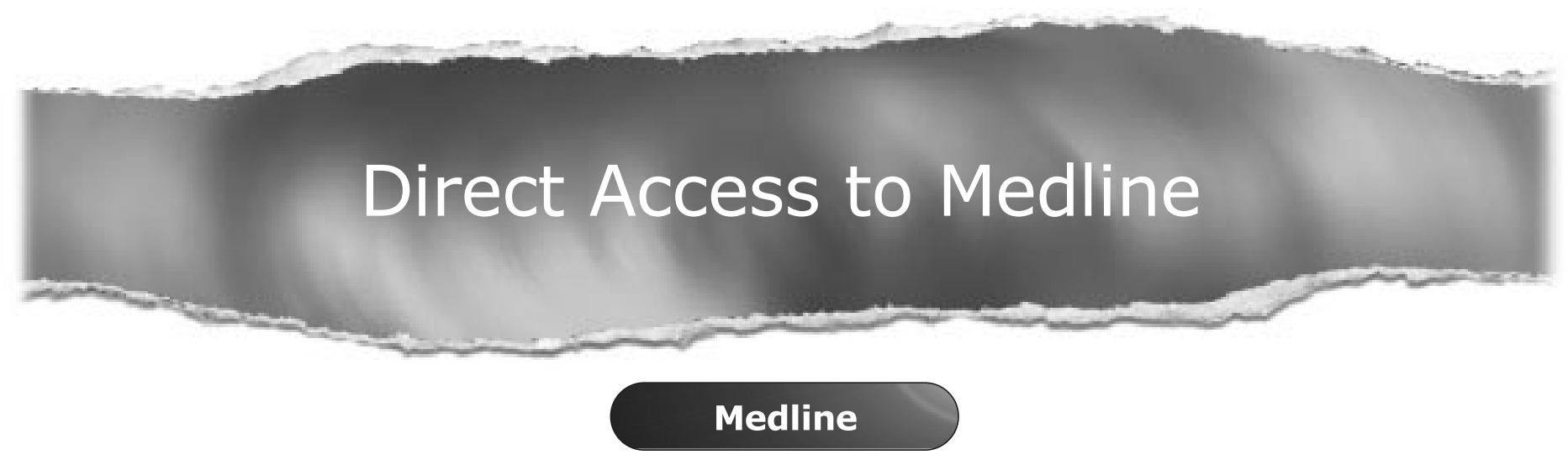

Link to Medline from the homepage and get straight into the National Library of Medicine's premier bibliographic database. Medline allows you to search across 9 million records of bibliographic citations and author abstracts from approximately 3,900 current biomedical journals.

\section{www.jech.com}

